\title{
Optimization and production of Alkaline Proteases from Agro byproducts using a novel Trichoderma Viridiae strain VPG 12, isolated from agro soil
}

\author{
Kirankumar Shivasharanappa ${ }^{1, a}$, Jayashree V. Hanchinalmath ${ }^{1, b}$, \\ Y. Sai Sundeep ${ }^{2, \mathrm{c}}$, Debajit Borah ${ }^{3, \mathrm{~d}}$, VSSL Prasad Talluri ${ }^{4, \mathrm{e}}$ \\ 1 Department of Biotechnology, Gulbarga University, Gulbarga - 585106, Karnataka, India \\ ${ }^{2}$ Department of Botany, Sikkim Central University, Gangtok - 737102, Sikkim, India \\ ${ }^{3}$ Centre for Studies in Biotechnology, Dibrugarh University, Dibrugarh - 786004, India \\ ${ }^{4}$ Department of Biotechnology, GITAM Institute of Science, GITAM University, \\ Vishakhapatnam - 530045, India \\ a-eE-mail address: kkwanegaon@gmail.com , jayhanchinal@gmail.com , \\ y.sai.sundeep@gmail.com , dborah89@gmail.com , talluri.chowdhary526@gmail.com
}

\begin{abstract}
In recent years, there has been a phenomenal increase in the use of alkaline proteases as industrial catalysts. The aim of this work was to isolate potent fungal strain from the agricultural field of Gulbarga region of India, for the production of alkaline protease by utilizing the agricultural by products viz, red and green gram and Bengal gram as substrate under submerged fermentation process. Optimization of fermentation process parameters such as substrate (Red gram husk, green gram husk and Bengal gram husk) utilization, utilization, temperature, $\mathrm{pH}$ and incubation period for alkaline protease production was carried out. The maximum production of alkaline protease by Trichoderma VPG 12 was found at $\mathrm{pH} 8$, temperature $35^{\circ} \mathrm{C}$, incubated for $120 \mathrm{~h}$. But the activity of the enzyme could also be seen in a wide range of $\mathrm{pH}(5-9)$ and temperature $\left(20-40^{\circ} \mathrm{C}\right)$. With all these properties, the strain can be considered for industrial grade production of alkaline protease.
\end{abstract}

Keywords: Alkaline proteases; Trichoderma viridiae; Agriculture byproduct; Red gram husk

\section{INTRODUCTION}

The present day trend is the utilization of waste material for production of byproducts, which boosts up high economic returns in many industries ${ }^{1}$. With the advent of biotechnology, attempts have increasingly been made globally to make potential use of agroindustrial residues for value addition by production of enzymes, organic acids, bioactive secondary metabolites, single-cell protein ${ }^{2}$.

Alkaline proteases (E.C.3.4.21.14) constitute one of the commercially important groups of extra-cellular microbial enzymes and are widely used in several industrial sectors, particularly in the detergent, food, pharmaceutical, chemical, leather and silk, apart from waste treatment ${ }^{3}$. These enzymes also have potential to contribute in the development of high 
value added products due to their characteristic nature of aided digestion ${ }^{4}$. Among all proteases, alkaline proteases are robust in nature and are primarily used as detergent additives $^{5}$. They account for $40 \%$ of the total worldwide enzyme sales and this trend is expected to increase in near future ${ }^{6}$. This has created increasing attention in exploitation of exotic microbial strains for production of alkaline proteases.

Red gram ranks sixth among pulses production in world and major legume crop. In India, it is the second largest pulse crop accounting about 20 percent of total pulse production. India annually produces about 2.0-2.5 million tones and stagnant in the past 10 years. The shift in cultivation from pulses to commercial crops and lack of technological innovations to increase yields has hindered the rise in output ${ }^{7}$.

The ability of Trichoderma strains to produce extracellular proteases has also been known for a long time; however, the proteolytic enzyme system is relatively unknown in this genus $^{8}$. Fortunately, in the recent years more and more attention is focused on the research in this field. The role of Trichoderma proteases in the biological control of plant pathogenic fungi and nematodes has been demonstrated, and it is suspected that they may be important for the competitive saprophytic ability of green mould isolates and may represent potential virulence factors of Trichoderma strains as emerging fungal pathogens of clinical importance 9 .

In view of the above, the present study was aimed for the Proteases production using agro wastes through submerged fermentation. In this study we report on the screening of VPG -12 for its ability of producing proteases using agro wastes such as Red gram, Green gram and Bengal gram husk and their protease production efficacy.

\section{MATERIALS AND METHODS}

\section{1. Micro-organism}

The microorganism used in the present study was Trichoderma viridae VPG-12 was isolated from the soil of agricultural waste depositing area and identified in our laboratory on the basis of $16 \mathrm{~S}$ rDNA sequencing. The $16 \mathrm{~S}$ rDNA sequence was submitted in NCBI GenBank.

\section{2. Chemicals}

Commercially available potato dextrose agar medium was purchased from HiMedia laboratories Pvt. Ltd., India. Lacto phenol Cotton Blue Stain, Casein, Trichloro acetic acid (TCA), sodium carbonate, Folin ceocalteau reagent (FCR) were procured from Merck India, Pvt. Ltd.

\section{3. Fermentation medium}

The production medium used was composed for $100 \mathrm{ml}$ of Distilled water was: Casein (40 g), Starch (10 g), Ammonium Chloride (8 g), Calcium chloride (5 g), Sodium phosphate $(2 \mathrm{~g})$.

\section{4. Substrate}

Red gram husk, green gram husk and Bengal gram husk were collected from Dal-mills and sundried, ground to particle size of 300-500 $\mu \mathrm{m}$ using standard sieves. 


\section{5. Inoculum Preparation}

Fifty milliliter of pre culture medium consisting of $0.8 \%$ potato dextrose broth was transferred to the cotton- plugged $250 \mathrm{~mL}$ Erlenmeyer flask and sterilized in an autoclave for $15 \mathrm{~min}$ at $15 \mathrm{Lbs}$ pressure at $121^{\circ} \mathrm{C}$ temperature. After cooling at room temperature, the flask was inoculated aseptically with a loopful of fungi from $48 \mathrm{hrs}$ old slant. The flask was then placed in the rotary shaking incubator at $37^{\circ} \mathrm{C}$ for $24 \mathrm{hrs}$. The bacterial growth was used as an inoculum in both the submerged fermentations ${ }^{10}$.

\section{6. Production of Alkaline Protease}

Submerged fermentation process was employed for production of alkaline proteases ${ }^{11}$. $100 \mathrm{ml}$ of production medium was added to $250 \mathrm{ml}$ Erlenmeyer flask, plugged with cotton, sterilized at $121{ }^{\circ} \mathrm{C}$ for $15 \mathrm{~min}$ at $151 \mathrm{bs}$ pressure, cooled and inoculated with loopful of fungal strain and incubated at room temperature for $120 \mathrm{hrs}$ under sterilized conditions.

\section{7. Extraction of crude enzymes}

After $120 \mathrm{hrs}$ of fermentation period the fermented media was filtered using wattsman's filter paper and centrifuged at $8000 \mathrm{rpm}$, at $4{ }^{\circ} \mathrm{C}$ for $15 \mathrm{~min}$ and the supernatant was used for analytical studies ${ }^{12}$.

\section{8. Assay for alkaline protease}

To $0.2 \mathrm{ml}$ of crude enzyme extract, $0.5 \mathrm{ml}$ of $1 \%$ casein and $0.3 \mathrm{ml}$ of $0.2 \mathrm{M}$ phosphate buffer $(\mathrm{pH} 7)$ were added and incubated at $60^{\circ} \mathrm{C}$ for 10 minutes and the reaction was arrested by addition of $1 \mathrm{ml}$ of $10 \%$ trichloroacetic acid.

The reaction mixture was centrifuged at $8000 \mathrm{rpm}$ for $15 \mathrm{~min}$ and supernatant was taken out. To supernatant $5 \mathrm{ml}$ of $0.4 \mathrm{M}$ of $\mathrm{Na}_{2} \mathrm{CO}_{3}$ and $1 \mathrm{ml}$ of 3 fold diluted folin ciocalteau phenol reagent was added and incubated at room temperature for $30 \mathrm{~min}$ and the absorbance of the developed blue colour was read at $660 \mathrm{~nm}$.

Using standard tyrosine curve amount alkaline proteases was calculated. One unit of enzyme activity was defined as the amount of enzyme that liberated $1 \mu \mathrm{g}$ of tyrosine substrate (casein) per minute under assay conditions ${ }^{13}$.

\subsection{Optimization of fermentation condition}

The fermentation process parameters such as $\mathrm{pH}$, temperature, incubation time, different substrates and concentrations that influence production of protease were optimized by varying the conditions.

The experiments were conducted in $250 \mathrm{ml}$ Erlenmeyer flasks containing production medium. After sterilization by autoclaving, flasks were cooled and inoculated with culture maintained under various optimal conditions separately such as $\mathrm{pH}(5,6,7,8,9)$ temperature $\left(20^{\circ}, 25^{\circ}, 30^{\circ}, 35^{\circ}, 40{ }^{\circ} \mathrm{C}\right)$, fermentation period $(24,48,72,96,120 \mathrm{hrs})$ and substrates (Casein, Red gram, Bengal gram, Green gram) after 120 hrs of fermentation, the culture filtrate was assayed foe protease activity ${ }^{14}$.

\section{10. Standardization of upstream Bioprocess}

A batch wise bioprocess was carried out as standard upstream bioprocess for the maximum production of proteases from red gram husk at optimized bioprocess variables such as $\mathrm{pH}$, temperature and fermentation period. In a $250 \mathrm{ml}$ Erlenmeyer flask $100 \mathrm{ml}$ of 
production medium was taken and sterilized by autoclaving and cooled at room temperature, to this a loopful of culture was inoculated and the process variables such as $\mathrm{pH}(8)$, temperature $\left(35^{\circ} \mathrm{C}\right)$ and fermentation period $(120 \mathrm{hrs})$ were maintained and the filtrate was taken for analytical study ${ }^{15}$.

\section{RESULTS}

\section{1. Effect of substrate concentration on protease production}

Various agricultural by products rich in protein content were screened for protease production. Among all the substrates, Red gram husk has shown good activity followed by Bengal gram and Green gram.

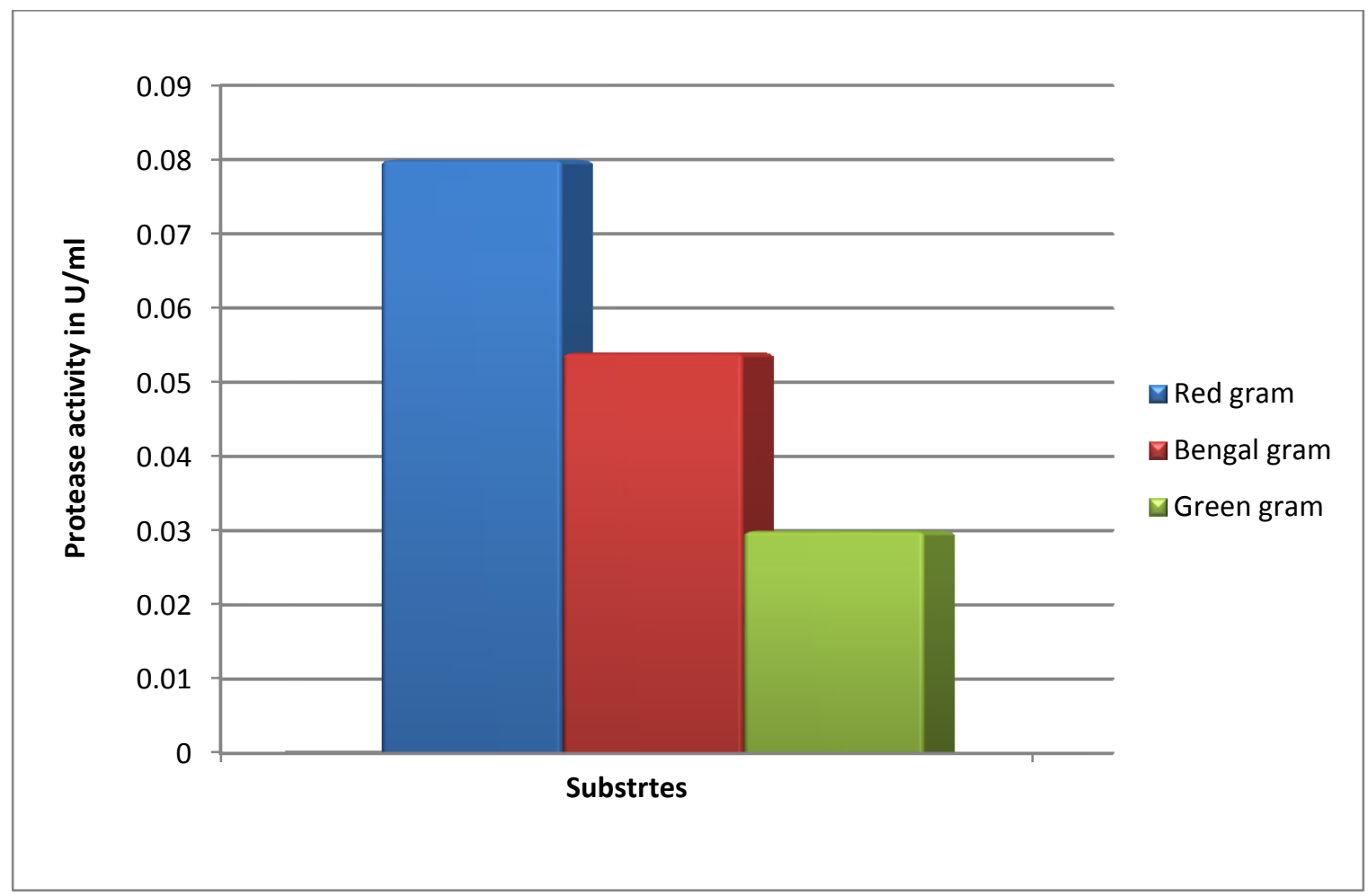

Figure 1. Effect of Substrate concentration on protease production.

\section{2. Effect of $\mathrm{pH}$ on protease production}

The maximum production of protease in submerged fermentation was observed at $\mathrm{pH} 8$. Figure 2 represents the effect of $\mathrm{pH}(\mathrm{pH} 5-9)$ on the production of protease. 


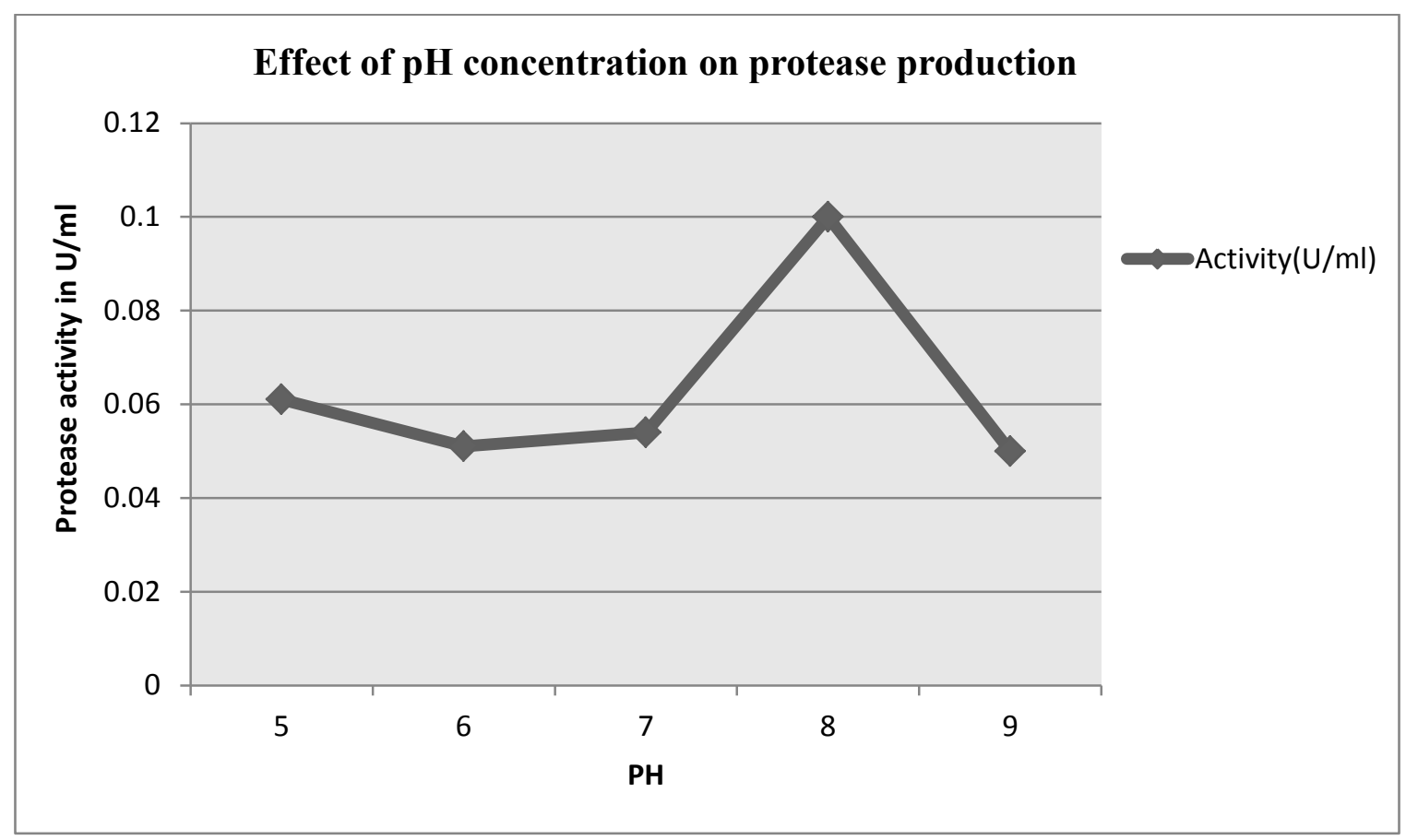

Figure 2. Effect of $\mathrm{pH}$ on protease production.

\section{3. Effect of temperature on protease production}

The optimum temperature $\left(20-40^{\circ} \mathrm{C}\right)$ for production of protease was depicted in Figure 3. Maximum activity was found at $35^{\circ} \mathrm{C}$ and minimum activity was found at $40^{\circ} \mathrm{C}$.

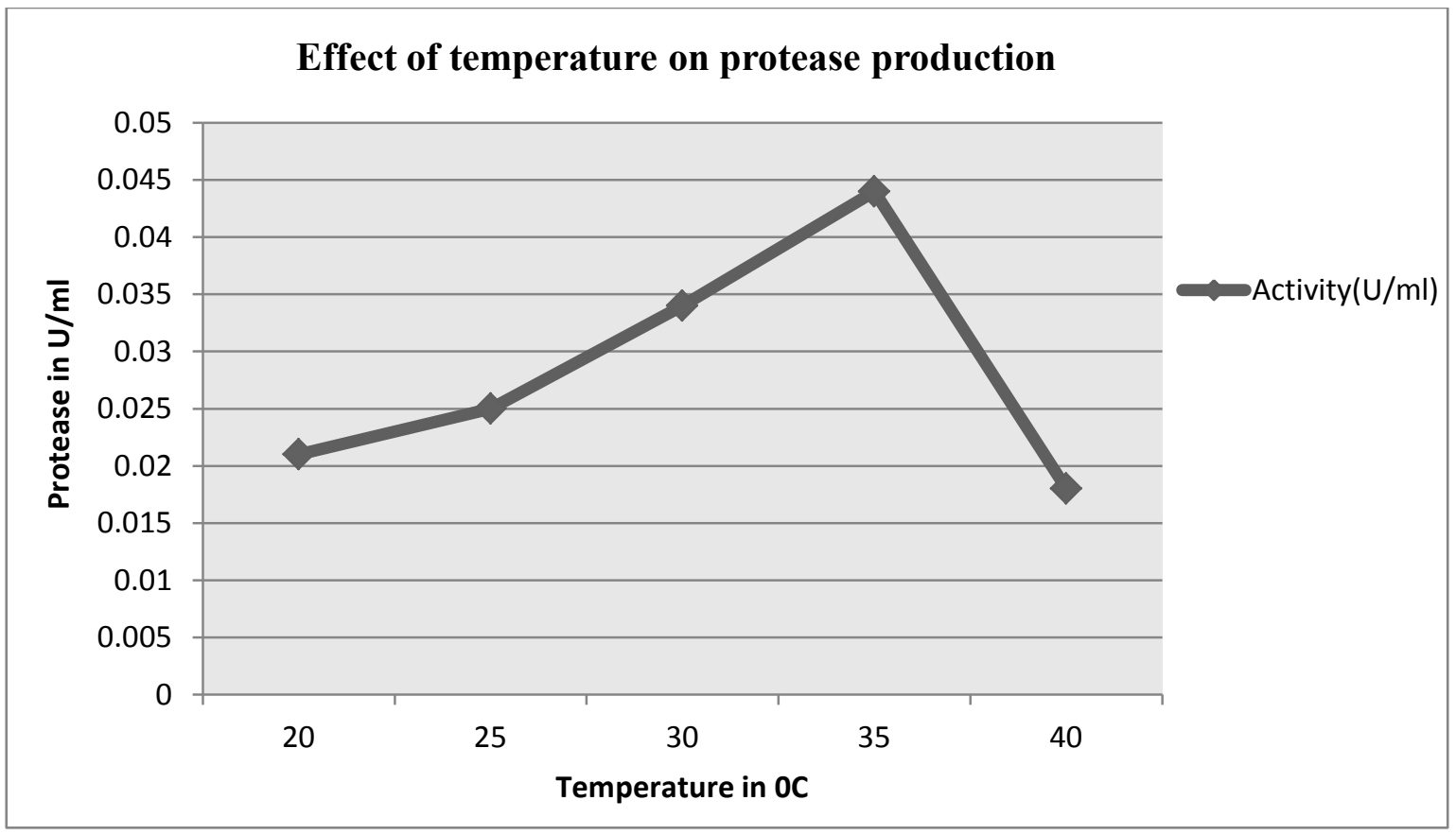

Figure 3. Effect of temperature on protease production. 


\section{4. Effect of fermentation period on protease production}

Highest yield of protease was observed in $120 \mathrm{hrs}$ of fermentation period. The effect of incubation period (24-120 hrs) on the production of protease from submerged fermentation is represented in Figure 4.

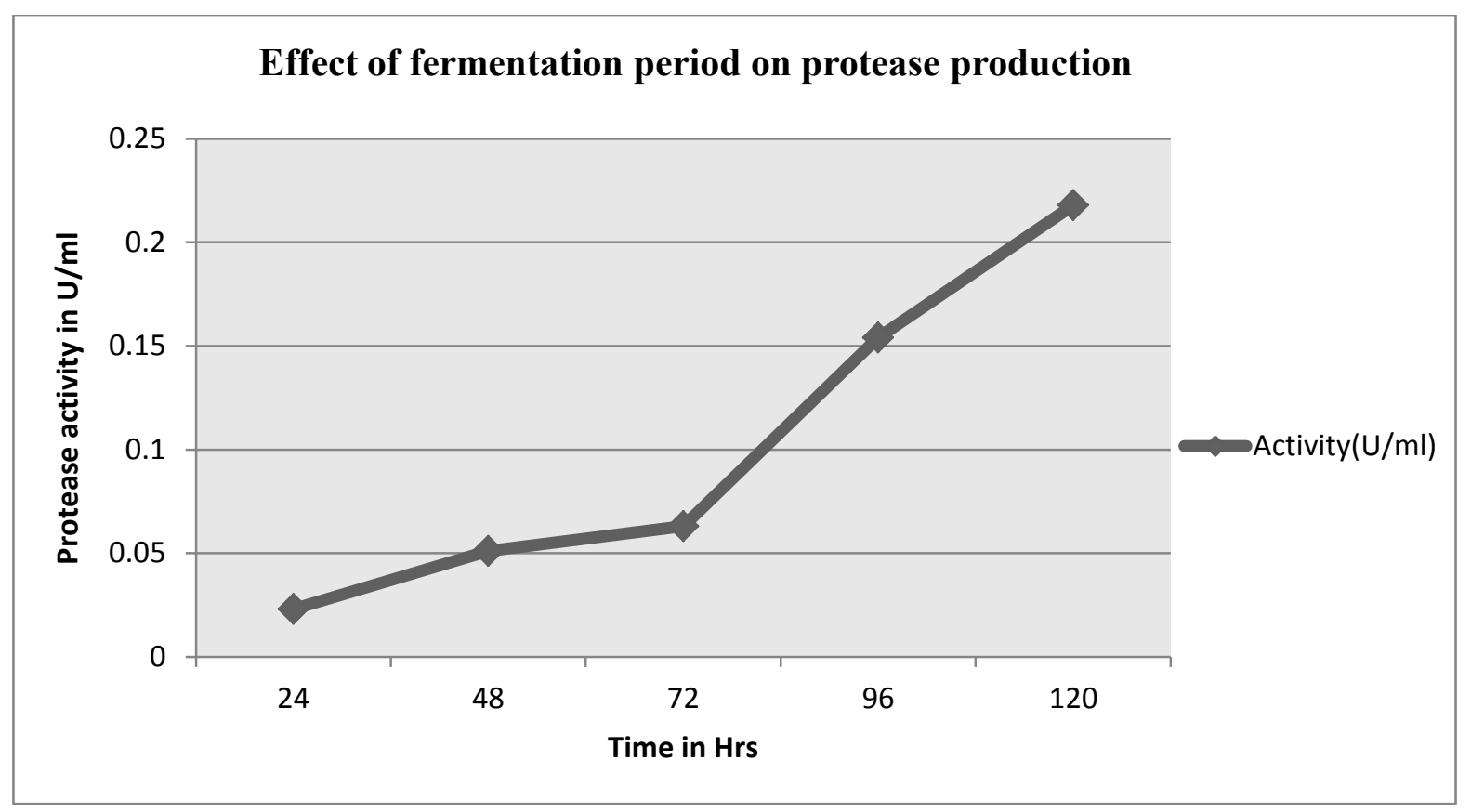

Figure 4. Effect of fermentation period on protease production.

\section{DISCUSSION}

The selection of an ideal agro industrial byproduct for enzyme production depends on several factors, which are mainly related to cost and availability of the material and thus may involve screening of several such byproducts ${ }^{16}$. During submerged fermentation, different agro industrial byproducts were evaluated for the production of alkaline protease by the organism, and red gram husk, which is a byproduct of Dal mills, was found to be the best protein substrate for the induction of protease production by VPG-12.

The present investigation revels significant valve regarding suitability of Red gram husk as a substrate for production of protease by indigenous strain Trichoderma VPG - 12, in submerged fermentation. Many fermenting organisms exhibit satisfactory growth over a broad range of $\mathrm{pH}$ with maximum growth at an optimum point ${ }^{17}$. Maximum activity was found at $\mathrm{pH}$ 8. The activity was slightly increased from $\mathrm{pH} 5$ to 7; again, yield was reduced at $\mathrm{pH}$ 9. Microbial growth rate as with all the chemical reactions is a function of the temperature of $25-35^{\circ} \mathrm{C}^{18}$. An attempt was made during the present study to access the influence of range of temperature $20-40{ }^{\circ} \mathrm{C}$ and the optimum production of protease was observed at $35^{\circ} \mathrm{C}$. The period of fermentation depends on the nature of media, fermenting organisms and physiological environment. In our study protease, activity was measured from $25 \mathrm{hrs}-120$ hrs. The highest activity was found at $120 \mathrm{hrs}$. The research and development strategies that are employed in finding the substrate and microbes of economic value and for developing their potential in a fermentation process are very crucial and important. The most successful 
approach to achieve this object is to understand the multifaceted interaction of the substrate and microorganisms during the course of fermentation. The protease production in standard upstream bioprocess employing Red gram husk in submerged fermentation with regard to efficiency of the strain VPG 12 is ideal in submerged fermentation.

\section{CONCLUSION}

Findings of the present study support the use of naturally available source for isolation of potent microbes and usage of agricultural by products for production of industrially important enzymes. The isolation and characterization of newer strains of Trichoderma species forever-continuous industrial use from natural sources, where they present in complex mixture is a most powerful means and inevitable. The detection of Trichoderma VPG12 for production of protease in submerged fermentation is most important contribution of the study.

\section{References}

[1] Ashokan P., Mohini S., Shyam R. A., Building and Environment 42 (2007) 2311-2320.

[2] Sumantha A., Larroche C., Ashok P., Food Technol. Biotechnol 44 (2) (2006) 211-220.

[3] Godfrey T., Leather in Industrial Enzymology 2 (1996) 285-291.

[4] McDonald C. E., Chen L. L., Analytical Biochemistry 10(1) (1965) 175-177.

[5] Ellaiah P., Srinivasulu B., Adinarayana K., J Sci Indstr Res 61 (2002) 690-704.

[6] Gupta R., Beg Q. K., Khan S., Chauhan B., Appl Microbiol Biotech 60 (2002) 381-395.

[7] Kalpana Devi M., Rasheedha B. A., Gnanaprabhal G. R., Pradeep B.V., Palaniswamy M., Ind J Science Tech 1(7) (2008) 1-6.

[8] Rao M. B., Tanksale A. M., Ghatge M. S., Deshpande V. V., Microbiol Mol Biol Rev 62 (1998) 597-635.

[9] Nakayama M., Tomita Y., Suzuki H., Nisizawa K., J Biochem 79 (1976) 955-966.

[10] Jeswani L. M., Baldev B., Adv in Pulse Pro Tech, Indian Council of Agricultural Research Publication (1988).

[11] Uchikoba T., Mase T., Arima K., Yonezawa H., Kaneda M., Biol Chem 382 (2001) 1509-1513.

[12] Manczinger L., Antal Z., Schoop A., Kredics L., Acta Biol Hung 52 (2001) 223-229.

[13] Lowry O. H., Rosebrough N., Farr A. L., Ronadall R. L., J. Biol. Chem 193 (1951) 265-273.

[14] Nehra K. S., Dhilon S., Chaudhary K., Singh R., Ind. J. Microbial. 42 (2002) 43-47.

[15] Joo H. S., Ganeshkumar C., Park G. C., Kim K. T., Seung R., Paik Chang C. S., Process Biochem 38 (2002) 155-159. 
[16] Gessesse A., Bioresour. Technol 62 (1997) 56- 61.

[17] Zwietering M. H., Jongenburger I., Rombouts F. M., Van't Riet K., Applied and Environmental Microbiology 56 (1990) 1875-1881.

[18] Malherbe S., Fromion V., Hilgert N., Sablayrolles J. M., Biotechnology and Bioengineering 86 (2004) 261-272. 